The Canadian Mineralogist

Vol. 43, pp. 311-325 (2005)

\title{
SLATY CLEAVAGE: DOES THE CRYSTAL CHEMISTRY OF LAYER SILICATES PLAY A ROLE IN ITS DEVELOPMENT?
}

\author{
Charles V. GUIDOTTI§ \\ Department of Geological Sciences, University of Maine, Orono, Maine 04469-5790, U.S.A. \\ FRANCESCO P. SASSI II \\ Dipartimento di Mineralogia e Petrologia, Università di Padova, C.so Garibaldi 37, I-35137, Padova. Italy \\ Paola COMODI and Pier F. ZANAZZI \\ Dipartimento di Scienze della Terra, Piazza Università, I-06100 Perugia, Italy \\ JAMES G. BLENCOE \\ Chemical Sciences Division, Oak Ridge National Laboratory, P.O. Box 2008, Oak Ridge, Tennessee 37831-6110, U.S.A.
}

\begin{abstract}
Much literature exists regarding processes by which shales are transformed into slates. Included are mechanical, physical, and chemical processes. We consider here some aspects not treated by previous authors. Specifically, we consider the manner in which, during such processes, certain special crystal-chemical and physical properties of phyllosilicates might strongly enhance both their ability to form and recrystallize with a strongly preferred orientation, and the development of the P and Q domains. Regarding the crystal-chemical aspects, we call attention to adjustments in the cell dimensions of muscovite and chlorite in response to compositional changes commonly observed when shale is syntectonically transformed into slate. Typically, in slates, the muscovite is phengite-rich, and the chlorite, relatively Al-rich. Phengite-rich muscovite has elongate $a$ and $b$ cell dimensions, but a markedly shortened $c$ dimension compared to pure muscovite. All three cell dimensions of Al-rich chlorite are shortened, especially in the $c$ dimension. These changes in cell dimensions in phengite-rich muscovite and chlorite, combined with effects expected according to periodic bond-chain theory, may well energetically facilitate the observed flattening. With regard to physical aspects, we point out the potentially important role of the unusually large compressibility of some phyllosilicates, especially along the $c$ cell dimension, and the control on it of the changes in mineral composition during slate formation. We suggest that to varying degrees, these special crystal-chemical and physical properties of phyllosilicates may contribute significantly to the relative ease of development of the typical structure of slates.
\end{abstract}

Keywords: slaty cleavage, white micas, chlorite, compressibility, crystal chemistry, periodic bond-chain theory.

\section{SOMMAIRE}

Plusieurs chercheurs se sont penchés sur les mécanismes de transformation d'un shale en ardoise, furent-ils mécaniques, physiques ou chimiques. Nous considérons ici certains aspects qui ont échappé aux auteurs antérieurs. Plus précisément, nous évaluons le rôle de certaines propriétés cristallochimiques et physiques des phyllosilicates au cours de la transformation et comment celles-ci pourraient augmenter leur abilité de se former et de recristalliser avec une forte orientation préférentielle, et ainsi développer des domaines de type P et Q. Par rapport aux aspects cristallochimiques, nous soulignons les ajustements des dimensions de la maille de la muscovite et de la chlorite résultant des changements typiques dans leur composition lorsqu'un shale est syntectoniquement transformé en ardoise. La muscovite des ardoises est typiquement enrichie en phengite, et la chlorite y est relativement riche en $\mathrm{Al}$. La muscovite enrichie en phengite possède des paramètres $a$ et $b$ allongés, mais une dimension $c$ beaucoup plus courte par rapport aux dimensions de la muscovite pure. Toutes trois dimensions de la maille élémentaire de la chlorite alumineuse sont courtes, spécialement le paramètre $c$. Ces changements en dimensions de la maille de la muscovite phengitique et la chlorite, pris en considération avec les effects attendus selon la théorie des chaînes de liaisons périodiques,

$\S \quad$ E-mail address: guidotti@maine.edu

II E-mail address: francesco.sassi@unipd.it 
pourraient bien faciliter l'applatissement observé. Nous soulignons aussi le rôle potentiellement important de la compressibilité anormalement élevée de certains phyllosilicates, spécialement le long de $c$, et la dépendance de cette propriété sur les changements compositionnels qui surviennent au cours de la transformation de shale en ardoise. Nous croyons que ces propriétés cristallochimiques et physiques spéciales des phyllosilicates pourraient bien contribuer de manière importante au développement de la structure typique de l'ardoise.

(Traduit par la Rédaction)

Mots-clés: clivage d'une ardoise, micas blancs, chlorite, compressibilité, cristallochimie, théorie des chaînes de liaisons périodiques.

\section{INTRODUCTION}

In science, one tries to understand phenomena and processes at ever more fundamental levels. In petrology, one seeks to understand the crystal-chemical responses of minerals to their imposed environment. Examples abound; for example, solvi close or cations disorder on sites as temperature increases, and the converse as temperature decreases. It was in this spirit that Guidotti et al. (2000) proposed a crystal-chemical explanation for the P-induced increase of the phengite content in muscovite, whereas coexisting paragonite (if present) deviates very little from its ideal end-member composition.

In order to understand rock deformation, investigators in structural geology and rock mechanics have typically considered physical features, e.g., the orientations in deformed rocks of $c$ axes of quartz or deformation lamellae in calcite. Few attempts have been made to interrelate mineral compositions and stress directions during deformation. As discussed below, past work by others and us on the petrological and mineralogical behavior of the $\mathrm{K}-\mathrm{Na}$ white micas and, to a lesser extent, on chlorites, has led to physical and chemical observations that may help to explain why white micas and chlorite become so strongly oriented during slate formation, at least in part due to crystallization of grains in the oriented direction despite the imposition of only very small differential stresses. Briefly stated, the crystalchemical behavior of $\mathrm{K}-\mathrm{Na}$ white micas in response to key petrological factors [P, T, $\left.a\left(\mathrm{H}_{2} \mathrm{O}\right)\right]$ is well known. Guidotti \& Sassi (1998a, b, and references quoted therein) and Guidotti et al. (1994) described the compositional changes that occur owing to metamorphic factors, and Guidotti et al. (1992, and references quoted therein) discussed the attendant changes in cell dimensions. The general compositional trends of chlorite in response to metamorphism also are fairly well known (Laird 1988, Guidotti et al. 1991, Zane et al. 1998, Vidal \& Parra 2000, Vidal et al. 2001), but less is known about associated responses thereto of cell dimensions. In terms of physical behavior, it was discovered early on (Hazen \& Finger 1978) that layer silicates (phlogopite and chlorite) are highly compressible, especially along the $c$ axis. Numerous subsequent studies confirm that in general, layer silicates are more compressible than other rock- forming phases, primarily because the $c$ unit-cell direction is always markedly more compressible than the other axial directions (see below), and that the compressibility of a given layer silicate can be affected by its composition (e.g., Comodi \& Zanazzi 1995, 1997). Moreover, although less widely recognized, in some slates muscovite and chlorite show systematic compositional differences depending upon whether or not flakes are parallel to the preferred orientation (e.g., Knipe 1979, 1981).

In this contribution, our goal is to discuss the possibility that some crystal-chemical features of layer silicates require important additional changes attendant with the other processes known to be involved in the formation of slaty cleavage. To this end, we present sequentially: (a) relevant information about the crystal chemistry and compressibility of the white micas (muscovite, paragonite, and phengite) and chlorite, (b) some discussion of the preferred orientation of phyllosilicates in slates, the related processes and the concomitant compositional changes in phyllosilicate, and (c) our suggestions that several of the crystal-chemical and physical properties of layer silicates might lead to greater atomistic understanding of some aspects of slate formation.

\section{Crystal Chemistry and Compressibility of ReleVANT LAYER-SILICATES}

\section{Crystal chemistry of dioctahedral white micas}

Figure 1A shows schematically a dioctahedral mica, a structure with which all Earth scientists are familiar. Figures $1 \mathrm{~B}$ and $1 \mathrm{C}$ illustrate less familiar additional relevant structural details. (1) Articulation of the apical atoms of oxygen with oxygen atoms on the sheets of octahedra requires that the tetrahedra deviate from a hexagonal to a ditrigonal array by means of rotation (called $\alpha$ rotation) of the tetrahedra essentially in the plane of the sheet. (2) This rotation reduces the space available for the interlayer cations, thereby forcing them somewhat out of the ditrigonal hole and thus also propping apart the 2:1 layers, and concomitantly, changing the coordination of the alkali cations from $\sim 12$ to 6 , i.e., approximately octahedral coordination. (3) In muscovite, $\mathrm{K}^{+}$is too large for this 6-coordinated site if the $\alpha$ rotation is maximum (Bailey 1984); consequently ac- 
commodation is achieved by: (i) decrease of the $\alpha$ rotation, (ii) propping apart of the 2:1 layers, and (iii) lateral stretching of the sheet of octahedra. Typical values of $\alpha$ are $11^{\circ}$ for muscovite and $16^{\circ}$ for paragonite.

Relevant physicochemical properties of muscovite and paragonite, including interrelationships among compositional characteristics, cell dimensions, and pressure $(\mathrm{P})$, are summarized in Table 1 (A and B, respectively). Excluding $\mathrm{Na} \Leftrightarrow \mathrm{K}, F m\left[=\Sigma\left(\mathrm{Mg}+\mathrm{Fe}_{\text {tot }}\right)\right]$ is the only important compositional deviation in these micas. It can be large in muscovite, but is invariably negligible in paragonite (Guidotti \& Sassi 1998a).

\section{Crystal chemistry of chlorite}

The crystal structure of chlorite is also universally familiar to Earth scientists. The key differences from mica are: the absence of interlayer alkali ion sites and the presence of two different types of layers, both of which contain a sheet of octahedra; one is brucite-like, $\left[\mathrm{Mg}(\mathrm{OH})_{2}\right]$, the other, talc-like, $\left[\mathrm{Mg}_{3}\left(\mathrm{Si}_{4} \mathrm{O}_{10}\right)(\mathrm{OH})_{2}\right]$. The sheets of octahedra can have varying proportions of $\mathrm{Mg}, \mathrm{Al}, \mathrm{Fe}^{2+}$, and small amounts of $\mathrm{Fe}^{3+}$. The sheets of tetrahedra of the talc-like layer can have varying amounts of Al replacing Si. These compositional variations produce a charge imbalance within the two types of layers that, along with a significant amount of hydrogen bonding, holds the two types of layers together. In contrast with the white micas (Guidotti \& Sassi 1998a, $\mathrm{b}$, and references therein), much less is known about the effects of compositional variations on the cell dimensions of chlorite. However, studies done by Jenkins \& Chernoski (1986), Roots (1994), and Baker \& Holland (1996) on Mg end-member chlorites all show qualita-

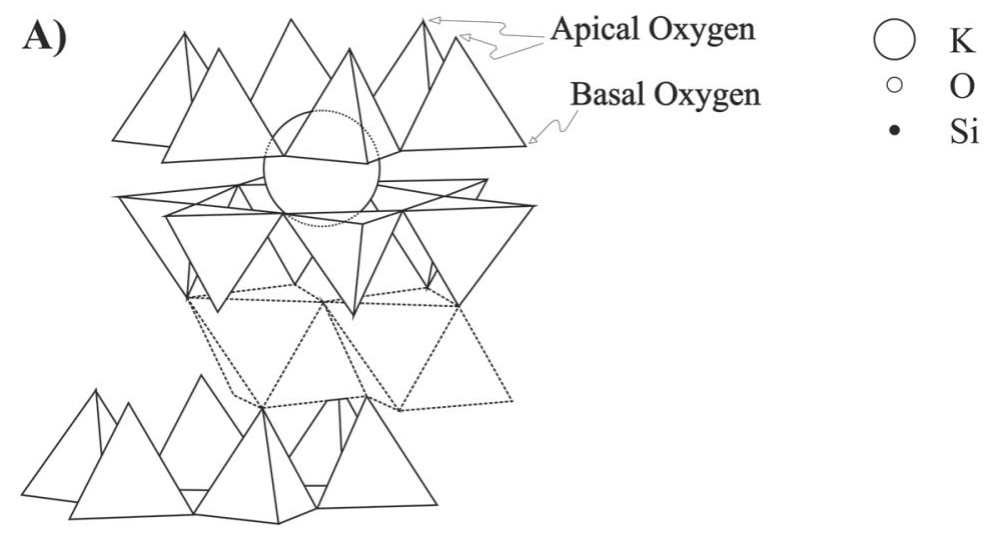

B)

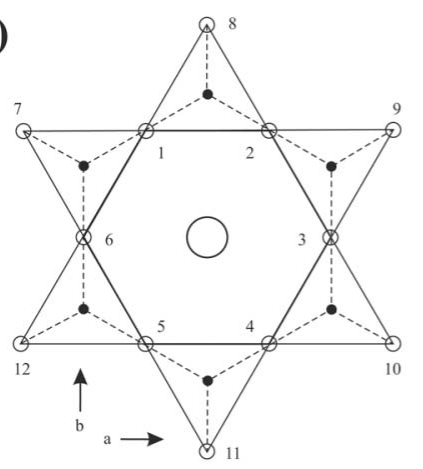

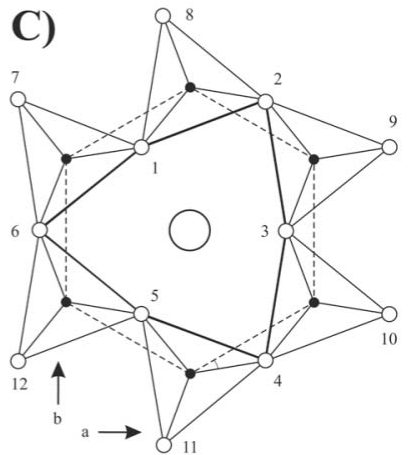

FIG. 1. Key aspects of the structure of a simple dioctahedral mica, based upon modifications of diagrams by Rule (1985) and Guggenheim (1984). (A) Simple illustration of the idealized sheets of tetrahedra, octahedra, and interlayer cations making up a dioctahedral mica. (B) Projection of a portion of the hexagonal array of tetrahedra in an idealized sheet of tetrahedra. (C) Rotation (angle $\alpha$ ) of the tetrahedra required to achieve articulation of the sheet of tetrahedra with the adjacent sheet of octahedra. 
tively that as Al increases in chlorite, the cell dimensions, especially that for $c$, decrease. Apparently, $c$ decreases from 0.5 to $0.8 \%$, respectively, over the compositional range from ideal clinochlore $[\mathrm{Al} /(\mathrm{Al}+$ $\mathrm{Mg}+\mathrm{Fe})=0.286]$ to the maximum $\mathrm{Al}$ permissible in a trioctahedral rock-forming chlorite $[\mathrm{Al} /(\mathrm{Al}+\mathrm{Mg}+\mathrm{Fe})$ $=0.4]$.

\section{Compressibility of layer silicates}

Differences between the types of bonding that hold the layers together in dioctahedral micas versus chlorite produce some distinct physical properties, including bulk and directional compressibility, as discussed below.

After the pioneering work of Hazen \& Finger (1978), important studies were conducted on the compressibility and thermal expansion of a number of key layer silicates. In some cases, measurements of these elastic properties were made separately, and in other instances concomitantly. Moreover, in some cases the work was done so as to determine the effects of both $\mathrm{P}$ and $\mathrm{T}$ on the details of the crystal structure. Table 2 summarizes some of the key results for phyllosilicates, along with corresponding results for a few other phases common in slates that are relevant to discussions presented in this paper. For the sake of uniformity and simplicity in making comparisons among the phases, the key data to consider in Table 2 are the percentage decreases in the

TABIE 1. SUMMARY OF ASPECTS OF MUSCOVITE AND PARAGONITE RELEVANT TO THE DEVELOPMENT OF SLATY CLEAVAGE

A) SOME RELEVANT COMPOSITIONAL ASPECTS*

(1) The formula of muscovite and paragonite (based on 22 atoms of oxygen): Muscovite $\quad \mathrm{XII}_{\mathrm{K}_{2}}{ }^{\mathrm{V}} \mathrm{Al}_{4}{ }^{1 \mathrm{~V}}\left(\mathrm{Al}_{2} \mathrm{Si}_{6} \mathrm{O}_{20}\right)(\mathrm{OH})_{2}$ Paragonite $\quad{ }^{\mathrm{XII}} \mathrm{Na}_{2}{ }^{\mathrm{VI}} \mathrm{Al}_{4}{ }^{\mathrm{IV}}\left(\mathrm{Al}_{2} \mathrm{Si}_{6} \mathrm{O}_{20}\right)(\mathrm{OH})_{2}$

(2) Maximum $\mathrm{Na} /(\mathrm{Na}+\mathrm{K})$ in muscovite: $c a .0 .38$ Minimum $\mathrm{Na} /(\mathrm{Na}+\mathrm{K})$ in paragonite: $c a .0 .8$

(3) $\quad F m=\Sigma\left(\mathrm{Mg}+\mathrm{Fe}_{\mathrm{T}}\right) . F m$ substitution involves substitution of $\mathrm{Fe}^{2+}, \mathrm{Mg}$, and $\mathrm{Fe}^{3+}$ for $\mathrm{Al}$ in VI sites, and as necessary, $\mathrm{Si}$ for $\mathrm{Al}$ in the IV sites. Thus, it involves two substitutions, the Phengite substitution: two substitutions, the Phengite substitution:
$\left[\left(\mathrm{Mg}_{\mathrm{F}} \mathrm{Fe}^{2+}\right)+\mathrm{Si}^{4+} \Leftrightarrow{ }^{\mathrm{v}} \mathrm{Al}+{ }^{\mathrm{V}} \mathrm{Al}\right\}$, e.g., toward $\mathrm{K}_{2}\left(\mathrm{MgAl}_{3}\right)\left(\mathrm{AlSi}_{7} \mathrm{O}_{20}\right)(\mathrm{OH})_{2}$, and the "Ferri Ms" substitution:

$\left[\mathrm{Fe}^{3+} \Leftrightarrow \mathrm{v}^{\mathrm{v}} \mathrm{Al}\right]$, e.g., toward $\mathrm{K}_{2}\left(\mathrm{Fc}^{3+} \mathrm{Al}_{3}\right)\left(\mathrm{Al}_{2} \mathrm{Si}_{6} \mathrm{O}_{20}\right)(\mathrm{OH})_{2}$

\section{(B) SOME RELEVANT EFFECTS OF PRESSURE}

(1) In response to an increase of pressure, $F m$ in muscovite increases, but both the value of the ratio $\mathrm{Na} /(\mathrm{Na}+\mathrm{K})$ and basal spacings decrease. In contrast, the $a$ and especially $b$ unit-cell dimensions increase.

(2) Although $c$ decreases as $F m$ increases, unit-cell volume increases because the increase in $a$ and $b$ more than compensates for the decrease of $c$

(3) $\mathrm{Fm}$ never occurs in significant amounts in paragonite regardless of the pressure.

(4) The solvus between paragonite and muscovite opens markedly with an increase in pressure, mainly because of the extensive movement of the limb on the muscovite side of the solvus; the paragonite limb moves very little.

* more details are given in Guidotti \& Sassi $(1998 \mathrm{a}, \mathrm{b})$

I more details are given in Guidotti \& Sassi (1998a) and Guidotti et al. (2000). unit-cell volumes and the $a, b$, and $c$ cell lengths that occur between $10^{5} \mathrm{~Pa}(1 \mathrm{bar})$ and $3.5 \mathrm{GPa}(35 \mathrm{kbar})$ as $\mathrm{T}$ increases from $25^{\circ}$ to $600^{\circ} \mathrm{C}$.

Judging from their bulk moduli $\left(\mathrm{K}_{0}\right)$, the $\mathrm{K}$-dominant white micas are highly compressible minerals Along the $c$ axis, compression is 3 to 5 times greater than along the $a$ or $b$ axis (in Table 2, compare the values listed in the column: Ratio of Max/Min). Indeed, the overall compressibility of these micas is substantially due to compression along the $c$ direction. Note that as $\mathrm{T}$ increases, the relative contribution of compression along the $c$ direction to cell-volume compressibility increases significantly. Although the data in Table 2 show that there are some compositional controls $[\mathrm{Na} /(\mathrm{Na}+$ $\mathrm{K})$ and phengite content] on the magnitudes of compressibility of muscovite, we will not consider them in detail here, as an insufficient number of measurements have been made to assess rigorously their significance quantitatively.

Considering only modern measurements of compressibility on chlorite-group minerals (Welch \& Crichton 2002, Pawley et al. 2002), it is evident that chlorite is not an especially compressible phase if compared to the micas (Table 2) and feldspars (Angel et al. 1988, Allan \& Angel 1997). However, as emphasized by Welch \& Crichton (2002), compressibility of a chlorite along its $c$ axis is significantly greater than along its $a$ and $b$ axes. These authors also provided a detailed discussion of the types of bonding and sites that explain the marked differences between the compressibility of micas and that of chlorite-group minerals.

Finally, a possibly surprising point apparent from Table 2 is that the bulk moduli $\left(\mathrm{K}_{0}\right)$ of quartz is actually less than that of the layer silicates, indicating that in terms of bulk-dimension properties, quartz may be the most compressible mineral present in a typical slate. Moreover, it exhibits greater compression along its $a$ axes than its $c$ axis. The total compressibility of albite is greater than that of chlorite-group minerals, but less than $\mathrm{K}$-dominant white micas, and also is less directionally controlled than the latter phases. A key feature seen in Table 2 is that only the layer silicates display a high degree of directionality in terms of the magnitude of their compressibility.

\section{Slate Formation and the CRYstal Chemistry of White Micas and Chlorite: Preferred Orientations in Slates and Related PRocesses}

Slates occupy enormous portions of most orogenic belts, and a vast literature exists on their origins and characteristics. Vernon (1998) reviewed most features of slates, the genetic interpretations, and debates related thereto. We sidestep these debates, discussing instead some mineralogical factors possibly bearing on previously unconsidered aspects of slate formation. For the sake of simplicity, we will only discuss the case of slates 
TABLE 2. COMPRESSIBILITIES OF LAYER SILICATES AND SOME OTHER RELEVANT MINERALS

\begin{tabular}{|c|c|c|c|c|c|c|c|c|c|c|c|c|c|}
\hline & $\begin{array}{c}\mathrm{P}(\max ) \\
\mathrm{GPa} \\
\text { for } \mathrm{K}\end{array}$ & $\begin{array}{c}\mathrm{T} \\
\text { cell }\end{array}$ & $\begin{array}{c}\mathrm{K}_{\mathrm{b}} \\
\mathrm{GPa}\end{array}$ & $\mathrm{K}_{0}{ }^{\prime}$ & $\begin{array}{l}\% \text { Decr } \\
\mathrm{V} \\
\text { cell }\end{array}$ & at $\sim 3$ & $\begin{array}{c}3.5 \mathrm{GP} \\
b\end{array}$ & $\begin{array}{ll}\mathrm{Pa} & \mathrm{Mc} \\
c^{c} & \\
& \text { di }\end{array}$ & $\begin{array}{l}\text { ax. dif } \\
\text { cell } \\
\text { imen. }\end{array}$ & $\begin{array}{c}\text { ff. Ratio } \\
\text { of }^{8} \\
{ }^{7} \mathrm{Max} / \mathrm{Min}\end{array}$ & Method & Reference & \\
\hline clinochlore & 7.7 & room & $81.0(0.5)$ & $4 *$ & 4 & 1.2 & 1.23 & 1.6 & 0.4 & $c: a=1.33$ & SPXRD & Welch \& Crichton (2002) & A \\
\hline $\begin{array}{l}\text { natural Mg-rich } \\
\text { chlorite }\end{array}$ & 3.6 & $200^{\circ} \mathrm{C}$ & $86.9(16)^{3}$ & $4 *$ & 3.38 & 0.92 & 0.88 & 1.68 & 0.8 & $c: a=1.91$ & SPXRD & Pawley et al. (2002) & B \\
\hline $\begin{array}{l}\text { natural Fe-rich } \\
\text { chlorite }\end{array}$ & 3.5 & $100^{\circ} \mathrm{C}$ & $86.9(16)^{3}$ & $4 *$ & 3.42 & 0.89 & 1 & 1.47 & 0.6 & $a: a=1.65$ & SPXRD & Pawley et al. (2002) & $\mathrm{C}$ \\
\hline clinochlore $^{5}$ & 6.3 & room & $86.9(16)^{3}$ & $4 *$ & 3.95 & 1.15 & 1.09 & 1.76 & 0.7 & $c: b=1.61$ & SPXRD & Pawley et al. (2002) & $\mathrm{D}$ \\
\hline phlogopite & 4.7 & room & $58.5(2.0)$ & $4 *$ & 5.58 & 0.9 & 0.98 & 3.58 & 2.7 & $c: a=3.98$ & single $\mathrm{cr}$. & Hazen \& Finger (1978) & E \\
\hline phlogopite & 12 & room & $49.7(5)$ & $8.6(2)$ & 5.50 & 1.1 & 1 & 3.4 & 2.3 & $c: b=3.40$ & SPXRD & Pavese et al. (2003) & $\mathrm{F}$ \\
\hline phlogopite & 6.5 & room & $54(2)$ & $7(1)$ & 5.30 & 1.0 & 1 & 5.1 & 4.1 & $c: b=5.1$ & single $\mathrm{cr}$. & Comodi et al. (2004) & G \\
\hline $\begin{array}{l}\text { muscovite } \\
\text { (high-Na) }\end{array}$ & 3.5 & room & $54(3)$ & $4^{*}$ & 5.44 & 0.83 & 1.05 & 3.59 & 2.8 & $c: a=4.32$ & single $\mathrm{cr}$. & Comodi \& Zanazzi (1995) & $\mathrm{H}$ \\
\hline $\begin{array}{l}\text { muscovite } \\
\qquad(\text { low-Na) }\end{array}$ & 3.4 & room & $49(3)$ & $4^{*}$ & 5.56 & 0.9 & 1.1 & 3.6 & 2.7 & $c: a=4.03$ & single cr. & Comodi \& Zanazzi (1995) & 1 \\
\hline $\begin{array}{l}\text { muscovite } \\
\qquad(\text { low-Na })^{6}\end{array}$ & 4.6 & room & $57.0(6)$ & $4 *$ & 5.3 & 1.1 & 1 & 3.5 & 2.5 & $c: a=3.5$ & SPXRD & Comodi et al. (2002) & $\mathrm{J}$ \\
\hline $\begin{array}{l}\text { muscovite } \\
\qquad(\text { low-Na })^{6}\end{array}$ & 4 & $300^{\circ} \mathrm{C}$ & $55.1(7)$ & $4 *$ & 5.5 & 0.7 & 0.62 & 4.0 & 3.4 & $c: b=6.4$ & SPXRD & Comodi et al. (2002) & $\mathrm{K}$ \\
\hline $\begin{array}{l}\text { muscovite } \\
\qquad(\text { low-Na) }\end{array}$ & 4.8 & $450^{\circ} \mathrm{C}$ & $51.1(7)$ & $4 *$ & 5.7 & 0.79 & 0.3 & 3.6 & 3.3 & $c: b=12.0$ & SPXRD & Comodi et al. (2002) & $\mathrm{L}$ \\
\hline $\begin{array}{l}\text { muscovite } \\
\qquad(\text { low-Na })^{6}\end{array}$ & 4.6 & $600^{\circ} \mathrm{C}$ & $48.9(5)$ & $4 *$ & 6.4 & 0.65 & 0.6 & 3.5 & 2.9 & $c: b=5.8$ & SPXRD & Comodi et al. (2002) & M \\
\hline paragonite & 4.05 & room & $65.0(20)$ & $4 *$ & 5.27 & 1.15 & 1.18 & 2.9 & 1.7 & $c: a=1.53$ & single cr. & Comodi \&Zanazzi (1997) & $\mathrm{N}$ \\
\hline paragonite & 5 & room & $54.9(5)$ & $4 *$ & 5.1 & 1.1 & 1.8 & 2.1 & 1.0 & $c: a=1.91$ & SPXRD & Comodi et al. (2002) & $\mathrm{O}$ \\
\hline paragonite ${ }^{6}$ & 4.4 & $450^{\circ} \mathrm{C}$ & $55.7(6)$ & $4 *$ & 5.5 & 0.8 & 1.02 & 2.1 & 1.3 & $c: a=2.66$ & SPXRD & Comodi et al. (2002) & $\mathrm{P}$ \\
\hline paragonite $^{6}$ & 4.4 & $550^{\circ} \mathrm{C}$ & $53.8(7)$ & $4 *$ & 5.7 & 0.5 & 0.6 & 2.1 & 1.6 & $c: a=4.2$ & SPXRD & Comodi et al. (2002) & Q \\
\hline phengite $-3 T$ & 5.3 & room & $55.8(5.7)$ & $8.9(4.0)$ & 4.61 & - & - & - & - & - & SPXRD & Pavese et al. (1999) & $\mathrm{R}$ \\
\hline phengite- $2 M_{1}$ & 7.4 & room & $57(3)$ & $9.2(1.7)$ & 4.82 & 0.78 & 1 & 3.15 & 2.4 & $c: a=4.04$ & single $\mathrm{cr}$. & Smyth ef al. $(2000)$ & $\mathrm{S}$ \\
\hline phengite- $3 T$ & 4 & room & $62(2)$ & $9 *$ & 4.4 & 0.63 & n.a. & 3.19 & 2.6 & $c: a=5.06$ & single $\mathrm{cr}$. & Smyth et al. (2000) & $\mathrm{T}$ \\
\hline alpha quartz & 8.9 & room & $37.12(9)$ & 5.99 & 7.21 & 2.75 & n.a. & 1.88 & 0.9 & $a: c=1.46$ & single $\mathrm{cr}$. & Angel et al. (1997) & \\
\hline
\end{tabular}

$\mathrm{K}_{0}=$ bulk modulus; $*$ Values fixed $\left(\mathrm{K}_{0\}}{ }^{\prime}=4\right.$ for a second-order Birch-Murnaghan equation of state). Values in parentheses are one standard deviation. (1) F-rich, a factor that should make its $c$-dimension compressibility greater than a "normal" (OH)-dominant phlogopite. (2) Calculated by Welch \& Crichton (2002) by fitting Hazen \& Finger (1978) data on chlorite. (3) Average of the three samples; values of K for axial direction provided by A.R. Pawley (pers. commun., July 2002). (4) Synthesized (900 C. 11 GPa) at near "tetrasilicic" composition; also very F-rich owing to the presence of topaz. (5) Same Chl as used by Welch \& Crichton (2002). (6) Effects on cell dimensions calculated relative to unit-cell values at room $P$. T for compositionally equivalent muscovite and paragonite, respectively, given in Comodi \& Zanazzi $(1995,1997)$. (7) Maximum difference between the $\%$ decrease at $\sim 35$ GPa of the most and least compressed unitcell dimension. (8) Roughly a measure of anisotropy in the compressibility. SPXRD: Synchrotron powder X-ray diffraction.

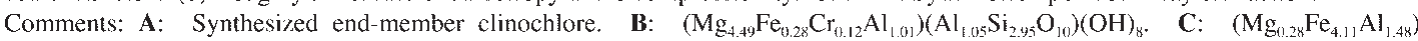
$\left(\mathrm{Al}_{1,23} \mathrm{Si}_{2.77} \mathrm{O}_{10}\right)(\mathrm{OH})_{8}, \quad \mathbf{D}:\left(\mathrm{Mg}_{5} \mathrm{Al}_{1}\right)\left(\mathrm{Al}_{1} \mathrm{Si}_{3} \mathrm{O}_{10}\right)(\mathrm{OH})_{8}$. E: Near end-member phlogopite, but very F-rich (see Footnote 1, above). F:

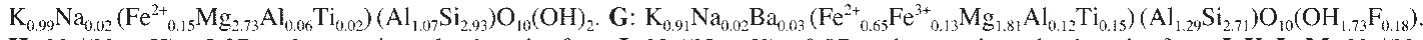
$\mathbf{H}: \mathrm{Na} /(\mathrm{Na}+\mathrm{K})=0.37$, and approximately phengite-free. $\mathbf{I}: \mathrm{Na} /(\mathrm{Na}+\mathrm{K})=0.07$, and approximately phengite-free. $\mathbf{J}, \mathbf{K}, \mathbf{L}, \mathbf{M}: \mathrm{Na} /(\mathrm{Na}$ $+\mathrm{K})=0.082$, and phengite-free. $\mathbf{N}: \mathrm{Na} /(\mathrm{Na}+\mathrm{K})=0.90$, and phengite-free. $\mathbf{O}, \mathbf{P}, \mathbf{Q}: \mathrm{Na} /(\mathrm{Na}+\mathrm{K})=0.95$, and phengite-free. $\mathbf{R}$ : $\mathrm{K}_{0.96} \mathrm{Na}_{0.01}\left(\mathrm{Al}_{1.44} \mathrm{Mg}_{0.56}\right)\left(\mathrm{Al}_{0.41} \mathrm{Si}_{3.59}\right) \mathrm{O}_{10}\left(\mathrm{OH}_{1.93} \mathrm{~F}_{0.07}\right)$. S: $\mathrm{K}\left(\mathrm{Al}_{1.21} \mathrm{Mg}_{0.75} \mathrm{Fe}_{0.04}\right)\left(\mathrm{Al}_{0.19} \mathrm{Si}_{3.18}\right) \mathrm{O}_{10}\left(\mathrm{OH}_{1.2} \mathrm{~F}_{0.8}\right)$ (see Footnote 4, above). T: $\mathrm{K}\left(\mathrm{Al}_{1,21} \mathrm{Mg}_{0.75} \mathrm{Fe}_{0.04}\right)\left(\mathrm{Al}_{0.19} \mathrm{Si}_{3.18}\right) \mathrm{O}_{10}\left(\mathrm{OH}_{1.2} \mathrm{~F}_{0.8}\right)$ (see Footnote 4, above). 
that experienced a single period of deformation in a prograde, sub-biotite-zone, greenschist-facies metamorphic event. Readers with little familiarity with slates are referred to Vernon's paper. For our purposes, only a few general points need to be extracted from his paper.

Slates form from shales, the latter mostly consisting of not easily characterized micas, chlorites and clay minerals that are variably oriented subparallel to bedding. During the transformation to slate, the layer silicates become very strongly oriented according to the prevailing differential stress, and become progressively better crystallized as an assemblage of predominantly white layer silicates (most typically a $2 M_{1}$ muscovite, but also possibly additional paragonite and pyrophyllite) and chlorite. Slates usually have a lenticular, foliated domainal structure (Fig. 2B). This structure has been related to deformation partitioning into high- and low-strain zones during the formation of the slate. The high-strain zones are called $\mathrm{P}$ domains, owing to an abundance of phyllosilicates (variable amounts of carbonaceous material and ilmenite occur there too). The low-strain zones are called Q domains since they are quartz-rich (and, depending on the slate, feldspars, typically albite, may also be abundant). Phyllosilicates are also present in $\mathrm{Q}$ domains, but are much less aligned than in P domains. Vernon (1998) also described a

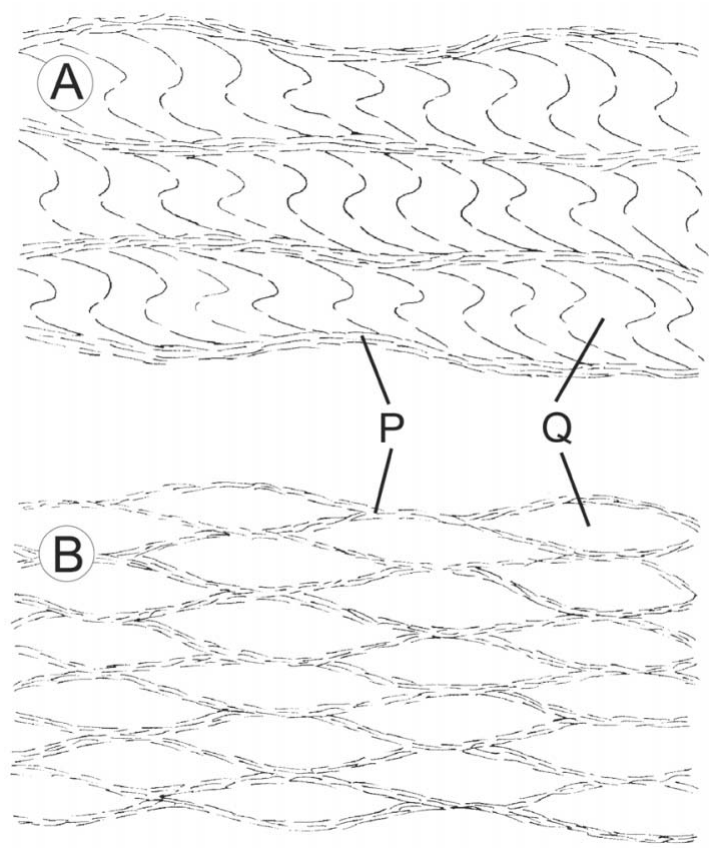

FIG. 2. Schematic examples of $P$ and $Q$ domains in slaty cleavage. (A) Example of a crenulation cleavage. (B) Example of a general case with lenticular $\mathrm{P}$ and $\mathrm{Q}$ domains. "crenulation cleavage" that forms in slates with a previous foliation, which in some cases may be a beddingparallel foliation. P and Q domains therein have the same significance with regard to strain partitioning as described above (Fig. 2A). In detail, textural differences exist between slaty and crenulation cleavage, but they are unimportant for present purposes.

The nature of the high strain in the $\mathrm{P}$ domains usually is not specified, but typically includes shortening in the direction perpendicular to the cleavage. In part, it may result from rotation of the platy minerals, but a key attendant process is dissolution of Qtz, which migrates from the $\mathrm{P}$ domains to form the $\mathrm{Q}$ domains. Commonly, there is also evidence for neocrystallization of layer silicates in the $\mathrm{P}$ domains and dissolution of these phases at the $\mathrm{Q}$ domain boundaries as well as within the $\mathrm{Q}$ domains. Supposedly, the strain also includes intergranular slippage along the (001) planes of the layer silicates. In aggregate, strain appears to involve shortening in slates (mainly in the $\mathrm{P}$ domains) perpendicular to the foliation, and stretching or elongation parallel to it (Gray 1997).

In summarizing his review, Vernon (1998, p. 224) stated: "that (1) cleavages, with compositional differentiation, may begin to develop at submetamorphic temperatures, and continue to develop with prograde metamorphism, and (2) mechanical rotation of detrital grains may dominate in the earlier stages, whereas solution and neocrystallization dominate in the later, probably most important, stages of cleavage formation". Vernon (1998, p. 224-226) also discussed the abundant evidence for solution of quartz from the $\mathrm{P}$ domains, and some evidence for its redeposition in the $\mathrm{Q}$ domains. Also discussed is the suggestion that dissolution of strained old grains (quartz and phyllosilicates) and neocrystallization of phyllosilicates in the $\mathrm{P}$ domains are the prime processes, especially in the later, higher- $T$ stages of slate formation; these stages are of principal concern here.

We fully concur with Vernon's views on slate-forming processes, and for our purposes restate them as: variably intergradational and partly interconnected (1) mechanical, (2) physical, and (3) chemical processes.

1) Creating a preferred orientation of phyllosilicate by mechanical processes implies lesser amounts of grain recrystallization, and mainly involves rotation of phyllosilicate grains [Williams 1972, Tullis \& Wood 1975, Tullis 1976, Urai et al. 1986; Oertel (1983) gave an extensive review] and crystallographic slip (Fairbairn 1949, Gonzalez-Bonarino 1960). Slip along crystallographic (001) planes of muscovite and chlorite might be related to formation of planes involving high shearstress or strain in a rock (at various angles to the axis of greatest shortening).

2) Physical processes include simple elastic strain and development of high densities of dislocations. These may facilitate recrystallization via dissolution and redeposition from a pore fluid (e.g., pressure solution) 
(Kamb 1959), grain-boundary migration, or solid-state diffusion (Urai et al. 1986, Stünitz 1998).

3) Chemical processes include all metamorphic reactions. They are probably only minor in the lower range of the temperatures at which slates form, but become dominant in the higher-T ranges. They can also facilitate recrystallization by dissolution and redeposition via a pore fluid (Holywell \& Tullis 1971, Paterson 1973, Etheridge et al. 1974, Wintsch 1978, Lee et al. 1986), grain-boundary migration, or solid-state diffusion.

Our main focus is on dissolution and redeposition in response to chemically driven processes, especially in the sub-biotite zone portion of the greenschist facies. Physically driven processes are secondary. Much literature exists for such a dissolution-driven process (e.g., Elliott 1973, Rutter 1983, Paterson 1995), and many terms with varying shades of meaning have been used for it. In this paper, we imply dissolution of less oriented muscovite and chlorite, and redeposition into a more preferred orientation, especially for cases involving concomitant changes of mineral compositions.

\section{Data on the Compositional Behavior of Muscovite and Chlorite During Slate Formation}

Key observations and data with potential implications for the crystal-chemical behavior of muscovite and chlorite during formation of preferred orientation of phyllosilicates in slates by dissolution and redeposition are discussed below.

\section{Muscovite and chlorite ccompositions in slate formation}

Observations by Sassi (1972) and Guidotti \& Sassi (1998a, b, and references quoted therein), and theory by Thompson (1979), indicate that in the sub-biotite zone, at greenschist-facies metamorphic conditions, $\mathrm{Fm}^{-}$ rich muscovite is stable in mineral assemblages typical of slates, and the Fm content of muscovite decreases at higher grades. Laird (1988, p. 414) discussed this point in further detail and also noted that the chlorite at this grade is richer in $\mathrm{Al}$ than it is in subgreenschist- facies rocks. More recent observations and theoretical approaches (Vidal \& Parra 2000, Vidal et al. 2001, Vidal, pers. commun., 2002) suggest that, under the conditions most typical for formation of slates, the chlorite becomes Al-enriched during the transition from subgreenschist- to greenschist-facies conditions.

\section{Compositional differences between oriented and unoriented muscovite and chlorite}

Probably as a consequence of the above considerations, systematic compositional differences between oriented and non-oriented flakes have been observed to occur, primarily in muscovite, but also in chlorite. For single-event slates, a growing body of observations (e.g., Knipe 1979, 1981, Li et al. 1994a, b, Ho et al. 1995; see also Vernon 1998, p. 226) reveals that oriented flakes of muscovite are enriched in $\mathrm{Fm}$ relative to unoriented grains. Muscovite oriented in the newly developed slaty cleavage ( $\mathrm{P}$ domains) also tends to be richer in Fm than the "older" muscovite in the intervening Q domains. Moreover, as with muscovite formed at high pressures (Guidotti et al. 1994, and references quoted therein), Fm-enriched muscovite in P domains is also both $\mathrm{Si}$ - and $\mathrm{K}$-enriched. Similar compositional differences between unoriented "porphyroclasts" of muscovite and the "neocrystallized" phengite defining the fabric associated with deformation have also been reported for mylonites (Dunlap et al. 1991). In conclusion, oriented phengite that replaces unoriented (possibly detrital muscovite) is more stable in the prevailing stress system. In some studies, oriented "new" chlorite has been observed to have chemical differences relative to unoriented grains. In the case of $\mathrm{P}$ domains, chlorite seems to become enriched in $\mathrm{Mg}$ and $\mathrm{Al}$ relative to the $\mathrm{Fe}$-rich, lower-Al chlorite in the $\mathrm{Q}$ domains (e.g., Stephens et al. 1979, Knipe 1981; see also consistent data in Li et al. 1994b).

\section{Related changes in cell dimensions}

In the case of muscovite, observations show that its cell dimensions change in response to pressure-induced variations in $F m$ content and $\mathrm{Na} /(\mathrm{Na}+\mathrm{K})$ (Guidotti et al. 1992, 2000). These variations occur because structural instability caused by internal strains at high $\mathrm{P}$ are mitigated by increases in $\mathrm{Fm}$ and decreases in $\mathrm{Na} /(\mathrm{Na}+$ $\mathrm{K})$. Assuming an $F m$ increase of 0.6 apfu with $\mathrm{Na} /(\mathrm{Na}$ $+\mathrm{K})=0.0$ for the "new" muscovite, its unit-cell dimensions would be markedly smaller along the $c$ dimension (by $\sim 0.05 \AA$ ), but larger along the $a$ dimension (by $\sim 0.021 \AA$ ) and especially the $b$ dimension (by $\sim 0.035$ $\AA$ ). (Note that for the respective dimensions, these changes are very large fractions $(39,12$ and 58\%) of the total ranges exhibited by muscovite in response to its total permissible compositional variation). The unit-cell volume of $\mathrm{Fm}$-enriched muscovite becomes slightly larger, but the increase is entirely in the direction along the (001) plane, which is parallel to the direction in which the slate as a whole is being flattened or extended.

In the case of chlorite, we noted above that its cell dimensions reflect chemical changes, as observed for muscovite. Assuming that the "new" Al-enriched chlorite retains its original $\mathrm{Mg} /(\mathrm{Mg}+\mathrm{Fe})$ value, all of its cell dimensions will decrease, but the decrease in $c$ will be greatest [as noted above, 0.5 to $0.8 \%$ for the $c$ axis over a range of 0.28 to 0.4 for the $\mathrm{Al} /(\mathrm{Al}+\mathrm{Fe}+\mathrm{Mg})$ ratio]. 
Related compressibility-induced behavior of muscovite and chlorite

In the case of muscovite, because of the compositional changes noted in the oriented $\mathrm{Fm}$-rich muscovite and the Al-enriched chlorite in the two previous sections, the "new" muscovite will tend to become more compressible as its $\mathrm{K} /(\mathrm{Na}+\mathrm{K})$ value increases (e.g., bulk modulus, $\mathrm{K}$, decreasing $\sim 10 \%$ for a $30 \%$ change in $\mathrm{K} /(\mathrm{Na}+\mathrm{K})$ value: see Table 2$)$, especially along the $c$ dimension. As seen from Table 2, the increase in phengite content will make muscovite somewhat less compressible in bulk; nonetheless, the very strong crystallographic anisotropy in the compressibility of muscovite still persists as a significant feature. With regard to chlorite, according to Pawley et al. (2002), compositional variation has little effect on any aspects of its compressibility.

The observations presented under the four previous subheadings suggest potential interrelationships among crystal-chemical characteristics of the phyllosilicates and various aspects of the processes that form slates, in particular, orientation of layer silicates, rock flattening perpendicular to cleavage, and rock elongation parallel to it. Hence, we have the question posed in the title of this paper, a response to which is outlined below.

\section{The Crystal Chemistry of Phyllosilicates: a Role in Slate Formation?}

Here, we consider three interrelated questions: (1) Chemical and metamorphic aspects: Do metamorphic and texturally controlled systematic differences in the composition of phyllosilicate minerals reveal the importance of dissolution and redeposition in the formation of preferred orientation of phyllosilicates in slates? (2) Nucleation and growth aspects: Do the accompanying crystal-chemical changes suggest new insights regarding some aspects of the nucleation, kinetics and energetics of the formation of a preferred orientation of phyllosilicates in slates? (3) Compressibility aspects: Does the highly anisotropic compressibility of phyllosilicates play a role in the formation of a preferred orientation of phyllosilicates in slates?

Considering these questions, our goal is to suggest how the particular crystal-chemistry, primarily of the $\mathrm{K}-$ $\mathrm{Na}$ white micas, and secondarily of chlorite, and possibly, their compressibilities as well, might contribute to formation of a preferred orientation of phyllosilicates in slates. Virtually all other aspects of slate formation are well covered in the review by Vernon (1998).

The discussion below has as its starting point Kamb's (1959) theory of preferred orientation induced by crystallization under stress. It extends the thermodynamic "theory of equilibrium under non-hydrostatic stress" of Gibbs to linearly elastic crystals under infinitesimal strain, and predicts that minerals subjected to differential stress will dissolve and reprecipitate with their weakest (i.e., most compressible) direction parallel to the axis of greatest principal pressure, obviously the typical case for muscovite and chlorite in slates. A few exceptions have been noted (e.g., Williams 1976, 1977, Henderson et al. 1986). However, some authors (e.g., Paterson 1973, 1995, Etheridge et al. 1974) suggested that differences in elastic energy alone are inadequate to cause such physically driven recrystallization. Nonetheless, Kamb's theory is still a starting point for many theoretical discussions of preferred orientations (e.g., Paterson 1973, 1995).

Since Kamb (1959), other theoretical models have been proposed for formation of slaty cleavage, some including the role of sheet silicates as an important, facilitating factor. However little or no attention has been given to the aspects on which we have focused here, i.e., chemical changes and associated crystal-chemical "peculiarities" (changes in cell dimensions and highly anisotropic compressibility).

\section{Discussion}

Generally, slaty cleavage is considered to be perpendicular to the direction of the strongest of the differential stresses that deformed the rock as the cleavage formed. Few data exist, but the magnitudes of the differential stresses are considered to be low, a few hundreds of bars at most, and possibly only a few tens of bars (Etheridge 1983, and references therein; see also Figure 24 of Shea \& Kronenberg 1992). Given such small differential stresses, it seems reasonable to conclude that the extreme preferred orientation of phyllosilicates in slates reflects various special features of the phyllosilicates, e.g., grain shape and grain rotation. However, where new, highly oriented grains of phyllosilicates nucleate and grow during dissolution and reprecipitation, we must consider the possibility that their strong orientation also reflects other "special attributes," including compositional and crystal-chemical behavior. These additional factors are discussed below.

\section{Chemical and metamorphic aspects}

Observations made under the first and second subheadings of the section entitled "Data on the compositional behavior of muscovite and chlorite during slate formation" indicate that, in agreement with Vernon (1998, p. 224), significant dissolution and reprecipitation of muscovite and chlorite must accompany the formation of highly developed slaty cleavage. It is difficult to propose ways to produce such an oriented structure that exclude significant contributions of dissolution and reprecipitation. This conclusion is strongly supported by the results of recent electron microscopy and X-ray work on layer silicates in slates (Van der Pluijm et al. 1998): these results suggest that grain deformation and mechanical rotation dominate in both lowergrade and lower-strain cases (lower total energy), 
whereas dissolution and reprecipitation dominate in both higher-grade and higher-strain situations (higher total energy). Although they dealt with a second-generation crenulation cleavage, differences in muscovite composition between P and Q domains led Worley et al. (1997) to a similar conclusion.

The observations thus made in the above-mentioned section deal with changes in mineral composition, i.e., chemically driven disolution and reprecipitation in the context of low-grade metamorphism. Recalling that our concern here is mainly "first-generation" slates that formed directly from shales, it should be noted that much of the white mica and chlorite present in typical shales is a mixture of detrital and diagenetic materials, including various clay minerals. As noted by Essene \& Peacor (1995), such "assemblages" are notoriously out of equilibrium. For the case considered here, we point out that: (i) the $\mathrm{Fm}$ enrichment of the oriented muscovite in the $\mathrm{P}$ domains is a manifestation, during formation of preferred orientation among phyllosilicate grains, of the initiation and progress of low-grade, truly metamorphic (as opposed to diagenetic) reactions, stimulated and driven by a combination of chemical and physical factors (see below); (ii) the measurable differences in muscovite and chlorite composition on the scale of $\mathrm{mm}$ between $\mathrm{P}$ and $\mathrm{Q}$ domains implies lack of equilibrium throughout the whole rock, i.e., the existence of only local equilibrium (see also Vernon 1998), but such a situation does not weaken the suggestion that the compositional and crystal-chemical behavior of muscovite and chlorite play a role in the development of their preferred orientation.

In a study dealing with a crenulation cleavage in rocks subjected to conditions of the upper greenschist to lower amphibolite facies, Williams et al. (2001) observed that the muscovite in the $\mathrm{P}$ domains (their $\mathrm{M}$ domains) shows a distinct tendency to be $F m$-enriched relative to the muscovite in the Q domains (their QF domains). It is interesting to note further that the $\mathrm{Fm}$ enriched muscovite shows the expected lower $\mathrm{Na} /(\mathrm{Na}$ + K) value (Guidotti \& Sassi 1998a).

The observations above are similar to those of Knipe $(1979,1981)$ and Lee et al. (1986) insofar as they both call upon a chemical drive to remove a metastable "assemblage" of minerals. Moreover, Carmichael (2000, 2001) and Wintsch \& Yi (2002) also included discussions of the influences of the operating stress-field in which the chemically driven dissolution and reprecipitation occurred. However, our suggestions are significantly different, in that none of these authors made mention of any crystal-chemical aspects of layer silicates (especially muscovite) that would serve to facilitate nucleation, growth, and chemical adjustments by the highly oriented muscovite in $\mathrm{P}$ domains.

The reactions that remove the metastable "assemblages" are typically high-variance cation exchanges. Hence, stating any specific details (e.g., balanced equations involving stoichiometric phases) for them is am- biguous, as they will depend on particular aspects of each given rock (e.g., its bulk composition, mineral assemblage, etc.). Because such reactions typically involve little or no changes in the modal amounts of the minerals, they involve little or no overall change in volume. Mainly, they involve compositional changes of the minerals and a radical change in shape of the rock.

\section{Nucleation and growth in a preferred orientation}

Potentially important aspects of muscovite that favor its nucleation and crystallization in a preferred orientation via dissolution and reprecipitation when subjected to differential stress are: (a) its observed chemical adjustments (see points made in the first two sections of the section entitled "Data on the compositional behavior of muscovite and chlorite during slate formation"), (b) the related changes of its cell dimensions (see the third subheading in the same section), (c) new insights regarding probable kinetic controls on the crystallographic directionality of layer-silicate growth (see below), and (d) more tentatively, its highly anisotropic compressibility and changes thereof as a function of composition (see fourth subheading). All of these factors are interdependent, through their relationships with the internal structure of muscovite (see section entitled "Crystal chemistry and compressibility of relevant layer silicates"). Below, we consider an atomistic interpretation of these relationships in terms of how they might facilitate growth of strongly oriented muscovite in slates. Although oriented chlorite is an intrinsic part of the preferred orientation of phyllosilicates in slates, its compressibility (at least the anisotropic aspects) and the response of its cell dimensions to its compositional changes are less dramatic than those of muscovite (see comparisons in the section "Crystal chemistry and compressibility of relevant layer silicates"). Possibly, these differences in compressibility, and response to compositional change between muscovite and chlorite, are the reasons why muscovite typically is more strongly oriented than chlorite in slates.

For the metamorphic P-T conditions at which a given slate forms, some particular compositions of muscovite and chlorite will have the lowest free energy. These compositions will also be a function of bulk composition (primarily the bulk Al content) (Guidotti \& Sassi 1998a, and references quoted therein). Among the original flakes of muscovite and chlorite, some probably will have compositions close to that of the lowest free-energy phase for the prevailing $\mathrm{P}, \mathrm{T}$, and $a\left(\mathrm{H}_{2} \mathrm{O}\right)$. Moreover, some of these flakes, either by happenstance or owing to variable amounts of rotation in the earliest stages of cleavage formation, will be oriented perpendicular to the direction of greatest differential stress. As discussed below, such grains should be more stable than unoriented grains of the same composition; consequently, they become the low-energy "sinks", toward which components needed for further nucleation and 
growth will flow. They will also serve as sites where $\mathrm{P}$ domains are initiated or enhanced, these locations being controlled by the given stress-field. Phyllosilicates with a different composition or orientation will have comparatively high free energy for chemical or for physical reasons (or both), the latter depending on the variable amounts of accumulated elastic strain, kinks, etc. Consequently, these phases will gradually dissolve, with the released chemical constituents migrating toward the above-mentioned "sinks". Ultimately, these materials will precipitate to form "new", oriented, lowfree-energy crystals, which, if continuously nourished, will create $\mathrm{P}$ domains. Flakes in, or close to, earlyformed $\mathrm{P}$ domains will be most readily converted, leaving flakes in more remote $\mathrm{Q}$ domains with non-equilibrium compositions, and hence, the above-described compositional differences between phyllosilicates in $\mathrm{P}$ and $\mathrm{Q}$ domains. Considering that in the development of $\mathrm{P}$ and $\mathrm{Q}$ domains, the quartz tends to dissolve and reprecipitate as well, reduction in surface free energy by increasing layer silicate - layer silicate and quartzquartz contacts also will be important. In addition, intergranular carbonaceous matter may inhibit grain growth, thereby favoring nucleation of new grains. This fact could explain the very fine grain-size of phyllosilicates in many slates.

Considering that formation of slates involves shortening of the rock in the direction parallel to the maximum differential stress, and elongation perpendicular to it, growth of appropriately $\mathrm{Fm}$-enriched muscovite grains oriented perpendicular to the differential stress should be the most favored circumstance for the following reasons: (1) shortening of the $c$ dimension of muscovite will enhance flattening of the slate. (2) Elongation of the $a$ and $b$ dimensions of muscovite will facilitate elongation of the slate. (3) The observed anisotropic compression of muscovite (and chlorite) agrees well with the predictions of Kamb (1959) (see further discussion below). (4) In muscovite, the increase of the rotation of tetrahedra, $\alpha$, with pressure, induced by the larger compressibility of layers of octahedra with respect to the layers of tetrahedra (see Guidotti et al. 2000), causes the destabilization of the mica structure. In fact, an $\alpha$ rotation that is too large could push together tetrahedrally and octahedrally coordinated cations, thereby increasing the electrostatic energy (Griffen 1992). Thus, chemical substitutions such as the increased incorporation of $\mathrm{Fm}$ observed for muscovite in the $\mathrm{P}$ domains, which reduce the $\alpha$ rotation, represent a crystal-chemical mechanism to increase the stability of mica.

Although much of the strain during formation of a slate also induces dissolution and reprecipitation of quartz, growth of such P domains would accommodate the strain physically or mechanically. Therefore, growth of such muscovite should further enhance the decrease in free energy that results from low-grade metamorphism.
Crystallization, by whatever means, of the most stable flakes of muscovite (and chlorite) as tabular aggregates (in locations controlled by the overall stressfield) will cause $P$ domains to thicken and expand laterally. This prediction follows from the observed tendency of layer silicates and other platy minerals to form layers of parallel flakes. Such layering develops because the surfaces of the phases have structurally compatible configurations of atoms, so that placing them against each other results in less increase in surface energy than if they were widely dispersed among grains of quartz and feldspar. Thus, completely or partially isolated flakes, even if they have the most stable possible composition and orientation, will still tend to dissolve and reprecipitate as $\mathrm{P}$ domains develop. For similar surfaceenergy reasons, quartz in the $\mathrm{P}$ domains will tend to dissolve and reprecipitate in $\mathrm{Q}$ domains.

The foregoing model of layer-silicate growth, serving to enhance $\mathrm{P}$ domains in slates, can be considered at a more fundamental level using the periodic bond-chain theory (Hartman 1973). The tendency for markedly enhanced rates of growth along [ $h k 0]$ directions by the compositionally most stable muscovite (and probably other layer silicates as well) appears to be well explained by this theory. Bickmore et al. $(2001,2003)$ have discussed in considerable detail the application of periodic bond-chain theory to both dioctahedral and trioctahedral 2:1 layer silicates, in order to better understand the growth and dissolution energetics of $\{h k 0\}$ faces. According to Bickmore et al. (2003), two periodic bondchains terminate (001) faces, but at most, only one terminates the $(h k 0)$ faces. Thus, the (001) faces should be least energetic, and thus will be more stable and grow more slowly. In contrast, the $(h k 0)$ faces will be more energetic and so will grow more rapidly.

Accepting the notion that that strain in slates is preferentially partitioned into $\mathrm{P}$ domains, some authors (e.g., Bell \& Rubenach 1983) have suggested that such movement includes slippage along the (001) planes of layer silicates. The discussion above does not bear directly on this possibility, but seems to be generally consistent with it. Indeed, nucleation of P domains as suggested above could serve as the initiating factor for this type of strain-energy release, and subsequently could serve as a factor that further stabilizes layer-silicate growth in $\mathrm{P}$ domains.

\section{Compressibility aspects}

Finally, we re-examine the suggestion considered above that the anisotropic nature of the compressibility of muscovite and chlorite may have significance in the development of slaty cleavage via dissolution and reprecipitation. It is uncertain whether the calculations suggesting that synmetamorphic stresses are inadequate to produce the recrystallization predicted by Kamb's theory took into account the large and highly anisotropic compressibilities of layer silicates. Muscovite, the 
most strongly oriented mineral in slates, typically is four to five times more compressible along the $c$ dimension than along the $a$ or $b$ dimensions; moreover, excluding quartz, it is more compressible than any other typical slate-forming mineral.

The pronounced shortening of the $c$ axis of muscovite during slate formation appears to be mainly attributable to changes in the composition of oriented muscovite as metamorphism proceeds, rather than to physical compression. In this regard, it should be noted though that muscovite with a low content of phengite shows considerable compressibility, especially along the $c$ dimension, even at 5-10 kbar of isotropic pressure (the $c$ dimension of low-Fm muscovite decreases by $\sim 0.1 \AA$ at $5 \mathrm{kbar}$, and by $\sim 0.2 \AA$ at $10 \mathrm{kbar}$, these values being somewhat larger than the decreases in c that result from the effects from any observed chemical changes, i.e., enrichment in Fm and K). Any additional increase in the compressibility of muscovite due to the amount of $\mathrm{K}$-enrichment that is observed for the oriented (phengitic) muscovite of slates should be modest [see Fig. 1 in Guidotti et al. (2000), the bulk modulus shown therein decreasing by $2-4 \%$ ]. However, in contrast, the increases of the $a$ and $b$ dimensions due to an Fm increase to 0.6 apfu are approximately the same as the decreases in those cell dimensions that occur as pressure is raised to $10 \mathrm{kbar}$. As seen in Table 2, increasing the $F m$ content of $2 M_{1}$ muscovite leads to some decrease of its bulk compressibility, mainly due to the opposing effects of $\mathrm{P}$ and $F m$ content on the $a$ and $b$ dimensions. Nonetheless, regardless of these possible compositionrelated countereffects on its compressibility, muscovite still remains a highly compressible phase, and its compressibility is markedly anisotropic. An important additional point is that the $c$ dimension will be shortened by both compression and any $\mathrm{Fm}$-enrichment. Moreover, the data available for K-rich, low-phengite $2 M_{1}$ muscovite (Table 2) show that the degree of directional anisotropy for its compressibility increases with increasing $\mathrm{T}$. Because of such factors, it seems to remain as a distinct possibility that the compressional behavior of muscovite is a contributing factor in the formation of preferred orientation of phyllosilicates in slates.

Finally, Knipe (1981) noted, in the rocks he studied, that paragonite does not occur in the $\mathrm{P}$ domains, but only in the Q domains. Although such a preferred localization of paragonite may not be a general rule (and different situations also are known, e.g., E.D. Ghent, pers. commun., 2004), it possibly reflects the fact that paragonite is less compressible than muscovite and does not withstand any substitution toward phengite, with attendant changes in cell dimensions (Guidotti \& Sassi 1998a, Guidotti et al. 2000). Both of these factors would inhibit its tendency to dissolve, nucleate, and recrystallize in a strongly preferred orientation within the growing $\mathrm{P}$ domains of slates.

\section{Concluding Remarks}

In this paper, we have stressed that dissolution and reprecipitation play a major role in the formation of slates, as discussed by Vernon (1998). The new contribution herein is the emphasis we give to the involvement of the crystal chemical and crystal physical properties in this process. Specifically, we emphasize how such dissolution and reprecipitation may be substantially facilitated by the combined compositional, crystal-chemical, and compressibility features of phyllosilicates and thus, potentially influence the formation of slaty cleavage.

Others authors have considered, with a variety of important details, dissolution- and reprecipitationinduced development of preferred orientation of phyllosilicates caused by chemical (metamorphic) reactions during deformation, enhanced by anisotropic aspects of the shape of grains (Etheridge \& Hobbs 1974, p. 122123, Etheridge et al. 1974, Tullis 1989, Dempster \& Tanner 1997). However, these authors give no direct consideration to any crystal-chemical aspects of the micas that might come into play. In contrast, we have explained how these aspects might serve as the trigger for dissolution of unoriented muscovite in the Q domains, and subsequent reprecipitation as highly oriented, Fm-enriched muscovite in the P domains. We have also postulated that muscovite (and probably other layer silicates, especially chlorite) reorient and recrystallize in a manner that drives dissolution and reprecipitation, facilitates rock flattening, and promotes the development of a preferred orientation of phyllosilicates. Furthermore, we point out that if quartz, with a compressibility much less anisotropic than muscovite, recrystallizes in a crystallographically preferred orientation driven and controlled by deformation, it is unrealistic to believe that the orientation of muscovite in slates is due entirely to grain rotation, especially in rocks subjected to greenschist-facies conditions.

It seems clear indeed that dissolution and reprecipitation are facilitated mainly by well-known low-grade metamorphic reactions among muscovite, chlorite, quartz, and plagioclase as chemical equilibria typical of greenschist-facies conditions are approached. With increasing grade of metamorphism, most of the unstable detrital and diagenetic minerals disappear (e.g., Laird 1988, Vidal \& Parra 2000, Vidal et al. 2001).

These developments, along with surface-energy effects (due to both crystal structure and kinetic factors reflecting periodic bond-chain theory) control the specific sites of nucleation and grain orientations that lead to both preferred orientation and pronounced $\mathrm{P}$ and $\mathrm{Q}$ domains. This metamorphic differentiation, in conjunction with any slipping along (001) planes of the phyllosilicates in the $\mathrm{P}$ domains, would serve to release elastic strain energy created during deformation, with most of the strain occurring in the $\mathrm{P}$ domains. Once oriented layer-silicates crystallize, there will be a tendency, 
as metamorphic grade increases, for further growth of the compositionally stable phases in a parallel orientation, even under static conditions (Ho et al. 2001).

As a final remark, the message given by Guidotti \& Sassi (2002) about the powerful scientific potential resulting from combining mineralogical and petrological studies may be extended to include combined crystalchemical and microstructural studies in order to get a deeper understanding of processes of deformation.

\section{ACKNOWLEDGEMENTS}

It is truly a distinct pleasure to participate in this volume, which is a recognition of Dugald Carmichael's long and distinguished contributions to virtually all aspects of metamorphic rocks. In particular, Dugald has been a major figure in emphasizing the interrelationships among metamorphism, deformation, and the mineralogical fabrics resulting from these interrelationships.

Many specialists on the deformation of rocks and the formation of slaty cleavage have helped us at various times and to varying degrees with their comments and suggestions. These gracious researchers, to whom we present our gratitude, include R. Angel, B. Bickmore, M. Brandon, D. Carmichael, T. Engelder, D.R. Gray, R. Hazen, W.B. Kamb, P. Koons, A. Kronenberg, G. Oertel, D. Peacor, L. Platt, K. Stüwe, T. Tullis, R. Vernon, O. Vidal, M. Welch, P.F. Williams, R. Wintsch and T. Wright. The authors gratefully acknowledge research support from the following sources: CVG: travel support from the University of Maine and from the Italian CNR via the "Short Term Mobility Program"; FPS: the Italian CNR, Institute of Geosciences and Georesources of CNR, MURST and University of Padova; PFZ: the Italian CNR and MURST (project on "Relations between structure and properties in minerals: analysis and applications); JGB: the Geothermal Technology Program of the Office of Energy Efficiency and Renewable Energy, U.S. Department of Energy, under contract number DE-AC05-96OR22464 with Oak Ridge National Laboratory, managed by Lockheed Martin Energy Research Corporation. Finally, we very much appreciate suggestions for improvements in our presentation by reviewers Ed Ghent, Herb Helmstaedt, guest Associate Editor Normand Bégin, and as usual, the very perceptive suggestions for wording and phrasing changes, to Bob Martin, Chief Editor of The Canadian Mineralogist.

\section{REFERENCES}

Allan, D.R. \& ANGEL, R.J. (1997): A high-pressure structural study of microcline $\left(\mathrm{KAlSi}_{3} \mathrm{O}_{8}\right)$ to $7 \mathrm{GPa}$. Eur. J. Mineral. 9, 263-275.

Angel, R.J., Allan, D.R., Miletich, R. \& Finger, L.W. (1997): The use of quartz as an internal pressure standard in high-pressure crystallography. J. Appl. Crystallogr. 30, 461-466.
Hazen, R.M., McCormack, T.C., Prewitt, C.T. \& SMYTH, J.R. (1988): Comparative compressibility of endmember feldspars. Phys. Chem. Minerals 15, 313-318.

BAILEy, S.W. (1984): Crystal chemistry of the true micas. In Micas (S.W. Bailey, ed.). Rev. Mineral. 13, 13-60.

(1988): Chlorites: structures and crystal chemistry. In Hydrous Phyllosilicates (Exclusive of Micas) (S.W. Bailey, ed.). Rev. Mineral. 19, 347-404.

BAKER, J. \& HOLLAND, T.J.B. (1996): Experimental reversals of chlorite compositions in divariant $\mathrm{MgO}+\mathrm{Al}_{2} \mathrm{O}_{3}+\mathrm{SiO}_{2}$ $+\mathrm{H}_{2} \mathrm{O}$ assemblages. Am. Mineral. 81, 676-684.

Bell, T.H. \& Rubenach, M.J. (1983): Sequential porphyroblast growth and crenulation cleavage development during progressive deformation. Tectonophys. 92, 171-194.

Bickmore, B.R., Bosbach, D., Hochella, M.F., Jr., Charlet, L. \& RUFE, E. (2001): In situ atomic force microscopy study of hectorite and nontronite dissolution: implications for phyllosilicate edge surface structures and dissolution mechanisms. Am. Mineral. 86, 411-423.

, Rosso, K.M., Nagy, K.L., Cygan, R.T. \& TADANIER, C.J. (2003): Ab initio determination of edge surface structures for dioctahedral 2:1 phyllosilicates: implications for acid-base reactivity. Clays Clay Minerals 51, 359-371.

CARMiChaEL, D.M. (2000): Deformation of slate and schist by diffusion metasomatism during prograde metamorphism. Aust. Geol. Soc., Abstr. 15, 71.

(2001): Deformation of polymineralic rocks by replacement creep. Keynote Presentation, Goldschmidt 2001 Meeting (abstr. on Goldschmidt 2001 CD).

Comodi, P., Gatta, G.D., Zanazzi, P.F., Levy, D. \& Crichton, W. (2002): Thermal equations of state of dioctahedral micas on the join muscovite-paragonite. Phys. Chem. Minerals 29, 538-544.

Montagnoli M., Zanazzi P.F. \& Fumagalli P. (2004): A single-crystal study on the pressure behavior of phlogopite and petrological applications. Am. Mineral. 89, 647-653.

\& ZANAZZI, P.F. (1995): High-pressure structural study of muscovite. Phys. Chem. Minerals 22, 170-177.

\& __ (1997): Pressure dependence of structural parameters of paragonite. Phys. Chem. Minerals 24, 274-280.

DemPSTER, T.J. \& TANNER, P.W.G. (1997): The biotite isograd, Central Pyrenees: a deformation-controlled reaction. $J$. Metamorph. Geol. 15, 531-548.

Dunlap, W.J., Teyssier, C., Mcdougall, I. \& Baldwin, S. (1991): Ages of deformation from K/Ar and ${ }^{40} \mathrm{Ar} /{ }^{39} \mathrm{Ar}$ dating of white micas. Geology 19, 1213-1216. 
ELLIOTT, D. (1973): Diffusion flow laws in metamorphic rocks. Geol. Soc. Am., Bull. 84, 2645-2664.

EsSENE, E.J. \& PEACoR, D.R. (1995): Clay mineral thermometry - a critical perspective. Clays Clay Minerals 43, 540553.

ETHERIDGE, M.A. (1983): Differential stress magnitudes during regional deformation and metamorphism: upper bound imposed by tensile fracturing. Geology 11, 231-234.

\& HoвBs, B.E. (1974): Chemical and deformational controls on the recrystallization of mica. Contrib. Mineral. Petrol. 43, 111-124.

, PATERSON, M.S. \& HobBs, B.E. (1974): Experimentally produced preferred orientation in synthetic mica aggregates. Contrib. Mineral. Petrol. 44, 275-294.

Fairbairn, H.W. (1949): Structural Petrology of Deformed Rocks. Addison Wesley, Cambridge, Massachusetts.

GonZALEZ-BonARINO, F. (1960): The mechanical factor in the formation of schistosity. Twenty-First Int. Geol. Congr. (Copenhagen) 18, 303-316.

GRAY, D.R. (1997): Volume loss and slaty cleavage development. In Evolution of Geological Structures in Micro- to Macro-scales (S. Sengupta, ed.). Chapman \& Hall, London, U.K. (273-291).

GrIFFEn, D.T. (1992): Silicate Crystal Chemistry. Oxford University Press, Oxford, U.K.

Guggenheim, S. (1984): The brittle micas. In Micas (S.W. Bailey, ed.). Rev. Mineral. 13, 61-104.

Guidotti, C.V., Mazzoli, C., Sassi, F.P. \& Blencoe, J.G. (1992) Compositional controls on the cell dimensions of $2 M_{1}$ muscovite and paragonite. Eur. J. Mineral. 4, 283-297.

\& SASSI, F.P. (1998a): Petrogenetic significance of $\mathrm{Na}-\mathrm{K}$ white mica mineralogy: recent advances for metamorphic rocks. Eur. J. Mineral. 10, 815-854.

\&

(1998b): Miscellaneous isomorphous substitutions in $\mathrm{Na}-\mathrm{K}$ white micas: a review, with special emphasis to metamorphic micas. Rend. Fis. Accad. Naz. Lincei 9, 57-78.

\& (2002): Constraints on studies of metamorphic K-Na white micas. In Micas: Crystal Chemistry and Metamorphic Petrology (A. Mottana, F.P. Sassi, J.B. Thompson, Jr. \& S. Guggenheim, eds.). Rev. Mineral. 46, 413-448.

Comodi, P., Zanazzi, P.F. \& Blencoe, J.G. (2000): The contrasting responses of muscovite and paragonite to increasing pressure: petrologic implications. Can. Mineral. 38, 707-712.

SASSI, R. \& Blencoe, J.G. (1994): The effects of ferromagnesian components on the paragonitemuscovite solvus: a semi quantitative analysis based on chemical data for natural paragonite-muscovite pairs. $J$. Metamorph. Geol. 12, 779-788.

Teichmann, F. \& Henry, D.J. (1991): Chloritebearing polymetamorphic metapelites in the Rangeley area, Maine: evidence for equilibrium assemblages. Am. Mineral. 76, 867-879.

Hartman, P. (1973): Structure and morphology. In Crystal Growth: an Introduction (P. Hartman, ed.). North Holland, Amsterdam, The Netherlands (367-402).

HAzen, R.M. \& FingeR, L.W. (1978): The crystal structures and compressibilities of layer minerals at high pressure. II Phlogopite and chlorite. Am. Mineral. 63, 293-296.

Henderson, J.R., Wright, T.O. \& HENDERSON, M.N. (1986): A history of cleavage and folding: an example from the Goldenville Formation, Nova Scotia. Geol. Soc. Am., Bull. 97, 1354-1366.

Holeywell, R.C. \& TulLis, T.E. (1971): Mineral reorientation and slaty cleavage in the Martinsburg Formation, Lehigh Gap, Pennsylvania. Geol. Soc. Am., Bull. 86, 1296-1304.

Ho, Nei-Che, Peacor, D.R. \& van der Pluijm, B.A. (1995): Reorientation mechanisms of phyllosilicates in the mudstone-to-slate transition at Lehigh Gap, Pennsylvania. J. Struct. Geol. 17, 345-356.

VAN Der Pluijm, B.A. \& Peacor, D.R. (2001): Static recrystallization and preferred orientation of phyllosilicates: Michigamme Formation, northern Michigan, USA. J. Struct. Geol. 23, 887-893.

Jenkins, D.M. \& Chernoski, J.V., JR. (1986): Phase equilibria and crystallochemical properties of Mg-chlorite. Am. Mineral. 71, 924-936.

KAMB, W.B. (1959): Theory of preferred crystal orientation developed by crystallization under stress. J. Geol. 67, 153170.

KNIPE, R.J. (1979): Chemical changes during slaty cleavage development. Bull. Minéral. 102, 206-209.

(1981): The interaction of deformation and metamorphism in slates. Tectonophys. 78, 249-272.

KreTZ, R. (1983): Symbols for rock-forming minerals. Am. Mineral. 68, 277-279.

LAIRD, J. (1988): Chlorites: metamorphic petrology. In Hydrous Phyllosilicates (S.W. Bailey, ed.). Rev. Mineral. 19, 405-453.

Lee, Jung-Hoo, Peacor, D.R., Lewis, D.D. \& Wintsch, R.P. (1986): Evidence for syntectonic crystallization for the mudstone to slate transition at Lehigh Gap, Pennsylvania, U.S.A. J. Struct. Geol. 8, 767-780.

Li, Gejing, Peacor, D.R., Merriman, R.J. \& Roberts, B (1994a): The diagenetic to low-grade metamorphic evolution of matrix white micas in the system muscovite- 
paragonite in a mudrock from central Wales, United Kingdom. Clays Clay Minerals 42, 369-381.

\& VAN DER PLUIJM, B.A. (1994b): TEM and AEM constraints on the origin and significance of chlorite-mica stacks in slates: an example from central Wales, U.K. J. Struct. Geol. 16, 1139-1157.

OerTel, G. (1983): The relationship of strain and preferred orientation of phyllosilicate grains in rocks - a review. Tectonophys. 100, 413-447.

PAterson, M.S. (1973): Non-hydrostatic thermodynamics and its geologic applications. Rev. Geophys. Space Phys. 11, 355-389.

(1995): A theory for granular flow accommodated by material transfer via an intergranular fluid. Tectonophys. 245, 135-151.

Pavese, A., Ferraris, G., Pischedda, V. \& Mezouar, M. (1999): Synchrotron powder diffraction study of phengite $3 \mathrm{~T}$ from the Dora-Maira massif, $\mathrm{P}-\mathrm{V}-\mathrm{T}$ equation of state and petrologic consequences. Phys. Chem. Minerals 26, 460-467.

, Levy D., Curetti N., Diella V., Fumagalli P. \& SANI, A. (2003): Equation of state and compressibility of phlogopite by in situ high-pressure X-ray powder diffraction. Eur. J. Mineral. 15, 455-463.

Pawley, A.R., Clark, S.M. \& ChinNery, N.J. (2002): Equation of state measurements of chlorite, pyrophyllite, and talc. Am. Mineral. 87, 1172-1182.

Roots, M. (1994): Molar volumes on the clinochlore-amesite binary: some new data. Eur. J. Mineral. 6, 279-283.

Rule, A.C. (1985): Mica Polytype Slide Set prepared by A. C. Rule. Available for purchase from: The Clay Minerals Society, <http://cms.lanl.gov/>, Aurora, Colorado 800460130, U.S.A.

RUTTER, E.H. (1983): Pressure solution in nature, theory and experiment. J. Geol. Soc. London 140, 725-740.

SASSI, F.P. (1972): The petrological and geological significance of the $b_{0}$ values of potassic white micas in low-grade metamorphic rocks. An application to the Eastern Alps. Tschermaks Mineral. Petrogr. Mitt. 18, 105-113.

Shea, W.T. \& Kronenberg, A.K. (1992): Rheology and deformation mechanisms of an isotropic schist. J. Geophys. Res. 97, 15,201-15,237.

\& _ (1993): Strength and anisotropy of foliated rocks with varied mica contents. J. Struct. Geol. 15, 1097-1121.

Smyth, J.R., Jacobsen, S.D., Swope, R.J., Angel, R.J., Arlt, T., Domanick, K. \& Holloway, J.R. (2000): Crystal structure and compressibilities of synthetic $2 M_{1}$ and $3 T$ phengite micas. Eur. J. Mineral. 12, 955-963.
StePHENS, M.B., Glasson, M.J. \& KeAYs, R.R. (1979): Structural and chemical aspects of metamorphic layering development in metasediments from Clunes, Australia. Am. $J$. Sci. 279, 129-160.

STÜNITZ, H. (1998): Syndeformational recrystallization dynamic or compositionally induced? Contrib. Mineral. Petrol. 131, 219-236.

THOMPSON, J.B., JR. (1979): Tschermak replacement and reactions in pelitic schists. Problems of Physical and Chemical Petrology 1, 146-159 (in Russ.).

TuLLIS, T.E. (1976): Experiments on the origin of slaty cleavage and schistosity. Geol. Soc. Am., Bull. 87, 745-753.

(1989): Development of preferred orientation due to anisotropic dissolution/growth rates during solution-transfer creep. Trans. Am. Geophys. Union (Eos) 70(15), $457-$ 458 (abstr.).

\& Wood, D.S. (1975): Correlation of finite strain from both reduction bodies and preferred orientation of mica in slate from Wales. Geol. Soc. Am., Bull. 86, 632-638.

Urai, J.L., Means, W.D. \& Lister, G.S. (1986): Dynamic recrystallization of minerals. In Mineral and Rock Deformation: Laboratory Studies (B.E. Hobbs \& H.C. Heard, eds.). Am. Geophys. Union, Geophys. Monogr. 36 (Paterson Vol.), 161-199.

Van der Pluijm, B.A., Ho, Nei-Che, Peacor, D.R. \& MerRiman, R.J. (1998): Contradiction of slate formation resolved? Nature 397, 348 .

VERNON, R.H. (1998): Chemical and volume changes during deformation and prograde metamorphism of sediments. In What Drives Metamorphism and Metamorphic Reactions? (P.J. Treloar \& P.J. O’Brien, eds.). Geol. Soc., Spec. Publ. 138, 215-246.

VIDAL, O. \& PARRA, T. (2000): Exhumation paths of high-pressure metapelites obtained from local equilibria for chloritephengite assemblages. Geol. J. 35, 139-161.

\& TROTET, F. (2001): A thermodynamic model for $\mathrm{Fe}-\mathrm{Mg}$ aluminous chlorite using data from phase equilibrium experiments and natural pelitic assemblages in the $100^{\circ} \mathrm{C}$ to $600^{\circ} \mathrm{C}, 1$ to $25 \mathrm{~kb}$ range. Am. J. Sci. 301, 557592.

Welch, M.D. \& CRIChTON, W.A. (2002): Compressibility of clinochlore to $8 \mathrm{GPa}$ at $298 \mathrm{~K}$ and a comparison with micas. Eur. J. Mineral. 14, 561-565.

Williams, M.L., Scheltema, K.E. \& Jercinovic, M.J. (2001): High-resolution composition mapping of matrix phases: implications for mass transfer during crenulation cleavage development in the Moretown Formation, western Massachusetts. J. Struct. Geol. 23, 923-939.

WiLLIAMS, P.F. (1972): Development of metamorphic layering and cleavage in low-grade metamorphic rocks at Bermagui, Australia. Am. J. Sci. 272, 1-47. 
(1976): Relationships between axial-plane foliations and strain. Tectonophys. 30, 181-196.

(1977): Foliation: a review and discussion. Tectonophys. 39, 305-328.

WINTSCH, R.P. (1978): A chemical approach to the preferred orientation of mica. Geol. Soc. Am., Bull. 89, 1715-1718.

\& YI, KEEWOOK (2002): Dissolution and replacement creep: a significant deformation mechanism in midcrustal rocks. J. Struct. Geol. 24, 1179-1193.
Worley, B.W., Powell, R. \& Wilson, J.L.W. (1997): Crenulation cleavage formation: evolving diffusion, deformation and equilibration mechanisms with increasing metamorphic grade. J. Struct. Geol. 19, 1121-1135.

Zane, A., SAssi, R. \& Guidotti, C.V. (1998): New data on metamorphic chlorite as a petrogenetic indicator mineral, with special regard to greenschist-facies rocks. Can. Mineral. 36, 713-726.

Received September 15, 2003, revised manuscript accepted July 14, 2004. 